\title{
Trade Dispute on Rare Earths Export from China to the United States
}

\author{
Jin Luo \\ School of Foreign Languages \\ Xijing University \\ Xi'an, China
}

\author{
Hongwei He \\ School of Politics \\ National Defence University \\ Nanjing, China
}

\begin{abstract}
The US and China have involved in trade disputes on rare earths resources since 2005 because of China's restriction on the export quotas. From the US firms' perspective, this paper will examine the negative impacts as well as benefits, if any, caused by China's rare earths export policies. Taking the US company, General Electric Company (GE) as an example, this paper mainly analyzes the GE's strategies to supply chain crisis and provides suggestions for its further development.
\end{abstract}

Keywords—rare earths; trade dispute; substitutes; material waste; suggestions

\section{INTRODUCTION}

Rare earth metals, as a set of 17 chemical elements in the periodical table, are not widely known, but because of special properties, they are the main contributors to hundreds of our everyday high-tech applications such as cell phones, iPads and LCDs. They are also critical to green energy industry including hybrid electric vehicles and wind turbines, even essential for defense systems and missile guidance. Therefore, it is not surprising that technology-oriented countries like the U.S. and Japan consider it an important international trade issue given the insufficient supply from their own lands.

According to the US Geological Survey (USGS), China accounts for half of the world's total rare earths reserves (most of which concentrates in the region of Inner Mongolia) and it currently shoulders over $95 \%$ of the global supply. Because importation from China is more cost effective, the US, once the leading rare earths producer closed its mining practices in 2002 and from then on almost entirely depended on China's rare earths resources.

So when Chinese government started to restrict the export quotas of rare earths since 2005, largely to control the environmental damages, prevent rare earths from overexploitation and to satisfy increasing domestic demands, trade dispute between these two countries occurred as China's move has far-reaching influence on related industries in the US.

This paper is designed from the US firms' perspective to examine the negative impacts as well as benefits, if any, caused by China's rare earths export policies. Through a case study of a US company called General Electric Company
(GE), the paper presents what responses GE takes to survive this supply chain crisis and suggestions are given for its further development.

\section{BACKGROUND: TRADE DISPUTE}

Down from 50,145 tons in 2009, Chinese export quotas declined by $40 \%$ in 2010 with 30,258 tons in total (Bloomberg, 2010). The move had demonstrated international trade implications which raised companies' concerns over high-valued rare earths and even limited access at any price. Data from the US Department of Commerce shows that between 2006 and 2010, US import value of rare earths from China rose by $314 \%$, from $\$ 22$ million to $\$ 91$ million (Berry and Torsekar, 2011), which result in the rising cost of production and impede US firms' further development.

As a result, on March 2012, the US gathered business groups as proof to file a trade complaint with WTO over China's export quotas on rare earths together with Japan and the EU, claiming that China's export policies aim at protecting its domestic business while threatening key industries in other countries such as green energy in the US. Following requests by the US, the WTO has set up a panel to probe China's rare earths export policies. As a response, China expressed its determination to continue reasonable protection for rare earths while making efforts to solve the dispute within WTO frameworks (Xinhua, 2012).

\section{CASE STUdY}

General Electric Company (GE), a leading clean energy company in the US, delivers advanced technology innovations from household appliances such as fluorescent bulbs to wind turbines and aircraft engines. Among the first 83 elements in the periodical table, GE has utilized 70 of them in at least one product (Brosnan, 2010), making it an obvious victim under China's policy. For companies like GE in whose products rare earths play an essential role, price inflation and resource shortage are fatal weaknesses.

The most direct impact is on sales market. GE is receiving more and more complaints from its customers for soaring price of compact fluorescent bulbs for which the average price rose by 37 percent in 2011. GE then released an explanation stating that costs of lighting production have 
increased from 500 percent to more than 2,000 percent in less than one year mainly because the main supply chain China has tightened its export quotas (FAQs). Moreover, high cost of wind turbine production offset government subsidies GE receives for green-tech industry which leaves the company much less money to invest in this area to further develop its research and meet its energy-saving goals. In the mean time, a huge price gap has been created between Chinese domestic market and overseas market, which gives Chinese firms a competitive advantage.

In order to reduce cost and be less dependent on rare earths, some companies have been working to change their business plans to look for substitutes, but most of them are less performing or the efforts ended up in vain. In this case, it is a waste of time and money which should be better deployed on employee recruitment, staff training and capital investment to increase their international competitiveness.

Moreover, in lighting industry, additional difficulties are attached to electrical contractors and distributors. Some special price agreements (SPAs) have to be redone because the continuing supply instability which caused price swinging has made the pricing no longer in effective. The situation also "force public agencies to make buying decisions sooner rather than later" in order to avoid further price rise, which leaves contractors more added scheduling and contractual issues to deal with, let alone the consequent cost and difficulty in the lighting upgrade sales pitch and a shrink of profit margin (Electrical Contractor, 2011).

There is also a fear over the fact that some US firms like Intematix (a phosphor producer), are moving their operations to China to secure a reliable and relatively low-cost of rare earths resources. China's intention is analyzed to benefit technology transfer from the cooperation of foreign and domestic companies in which way it could fulfill its goal of building a more sophisticated rare earth industry (Morrison and Tang, 2012). Despite this, the trend is considered highly risky for foreign investors of the possible intellectual property rights violation and industrial espionage.

Positive sides of the policy, however, are not to be neglected. Evidently, this is a good news for Chinese industry. Their easier and cheaper access to rare earths has largely widened the price gap and gained themselves competitive advantages over international competitors. Meanwhile, the downstream industries in China are speeded up by the export policies because foreign companies prefer to buy finished goods rather than raw materials, which enable Chinese manufacturers to produce more value-added products and regain their market control.

On the other hand, despite price suffers, big companies like GE may profit from the supply disruption in the long run. In the wake of China's export restrictions, GE has realized that high dependence on China is not a permanent solution for its sustainable development and it has pushed up researches on projects aimed at reducing the use of rare earths, in which way it can even lower the cost and improve product quality. GE's achievements will be explained in the next section.
From a global perspective, China's move has given rise to the operation of mine sites in some countries. Molycorp, one of the world's leading rare earths companies in the US reopened Mountain Pass mine (California) in 2012. Its output for 2011 was $3.5 \mathrm{k}$ tons and is estimated to reach $19 \mathrm{k}$ tons by the fourth quarter of 2012 (Risk, 2012). Another large rare earths mine in Australia has also come into production which is expected to ease the rising demand of rare earths globally.

\section{GE'S RESPONSES}

While the US government is negotiating with China to reach fair and balanced trade policies on rare earths, US companies are fighting their own ways to survive this crisis. As a world class company, GE has taken a quick reaction which may offer some tips to other companies.

Firstly, GE organized special teams to deal with the unprecedented situation, assuring a faster and more focus response to rare earth issues. It also created an FAQ section on its official website to answer customers' questions regarding concerns about rare-earth-related products from "Why are costs so rapidly changing?" to "What is GE doing to combat the rare earth supply chain crisis?" (FAQs). By giving satisfying and reasonable reply, GE's credibility among its customers increased thus reduced the risk of customer loss under the same situation for other counterparts.

However, to fundamentally solve the problem of resource shortage, other measures taken by GE include limitation of manufacturing waste, different ways for recycling, developing technologies to reduce or replace the use of rare earths, working with the government and sourcing out for more suppliers.

Material waste during manufacturing process may be easily ignored especially by big companies but it is a feasible solution to save resources in the short term. Steven Duclos, GE's chief scientist, estimated that simple adjustment of manufacturing processes to reduce waste along the production line could possibly decrease rare earths demand from $10 \%$ to $80 \%$ because most processes were designed without considering economical use of the material (Shumsky, 2011).

This approach called pre-consumer items recycling is to limit metals used in the waste stream while post-consumer products recovering is what normally conducted in many factories and GE has carried out this course in several ways.

Early in 2006, GE Aviation started the GE Reclamation Program to mitigate the need for rare earth metals. Besides component innovation and new alloys, recycling materials from deserted engine parts is an effective way to reduce rhenium demand and lower the costs in jet engine production. With this approach, the Program has generated an abundant supply stream of rhenium and by 2009, GE recovered thousands of pounds in recycling rhenium-based alloys (GE Citizenship).

GE has also developed global recycling partnership with metal-processors and scrap-metal companies which could 
provide a collection of unserviceable components and reintroduce them into GE's supply chain with fullyprocessed form. In addition, GE's customers are offered massive benefits from returning scrap metals (GE Citizenship).

While it is not easy for companies to get themselves out of hardship in a few years time, medium and long term solutions have been sorted out. Many US firms and research institutes are engaged in searching for substitutes and developing alternative technologies to reduce or eliminate rare earth elements in their products. GE obviously owns advantages over other companies with a research basis called GE Global Research with thousands of experienced lab technicians working on new technologies rather than specific products and they are given a long time (usually seven to ten years) and a substantial sum of money to focus on their research.

GE Global Research has been working with the Department of Energy (DOE) on a project to develop nanocomposite magnet materials which contain less rare earth elements such as neodymium, dysprosium and terbium. If succeeds, the nanotechnology is believed to take over the market with greater magnetic properties thus even lighter batteries than what we are using today in devices and vehicles (Kaye, 2011). The technology is promising but it may take years of efforts for GE to gain the ability to manufacture the needed nanocomposites at a required scale. In addition, under ARPA-E (Advanced Research Projects Agency-Energy) projects, iron-based bulk magnets with $80 \%$ less rare earth metals are being studied by GE which can deeper commercialize HEVs, EVs and wind turbine generators in the international market (ARPA-E, 2009). By 2010, through experiments and tests, GE successfully found several new alloys which could decrease rhenium use. Recently, GE announced a new product called "super alloy" which can take the place of rare earths but a long period is needed until it enter the market (Industry News, 2012).

It is worth noticing that for this project, with sufficient funding, GE has seized the opportunity to work with the US government DOE on the ARPA-E projects to develop less rare earths applied magnets. In fact, several projects on green energy are underway in the collaboration of these two parties. GE's business representatives across the US and Europe maintain a good relationship with government teams within industrial activities. There is no doubt about the wise choice of commerce and politics association which is in the best interest of companies for they can receive additional help with development, get business-related information in advance and gain more government subsidies.

With a strong support by its division of GE Global Research and the government, it is still in fact not easy for GE to find effective substitutes that could meet the demand for rare earths. Many high-tech firms are also engaged in R\&D researches. The result noted by US Geological Survey is that although many products have contained substitutes, the general result is not as effective as their predecessors.

From a large picture, the demand for rare earths will continue outpacing supply which has spurred a global tendency of rare earth mining reopening. Taking advantage of this trend, GE has been sourcing for diversified suppliers from its backyard in the US to Australia and Canada. Companies led by GE even proposed to the US Congress to accelerate the production of rare earths which helped to draw more attention of this event. However, Challenges appears for new mines. Purchase and operation of mining facilities requires a huge amount of investment in the first place and the time before mines come into operation could last from seven to ten years. Furthermore, improving environmental requirements, rising labor wages and lack of skilled workforce have hindered the progress of rare earths production. On the other hand, the already reopened two mines aforementioned in the US and Australia are expected to output more metals over time. Unfortunately, they mainly contain light rare earths rather than medium and heavy terms which are essential for many electronic products. Therefore, with sufficient supply of both light and heavy rare earths, China will continue to dominate rare earth industry worldwide (Morrison and Tang, 2012).

Despite GE's efforts in this supply disruption, other companies in the US have also accomplished some achievements. For example, Hybrid Electric Vehicle Technologies (HEVT), a company in Chicago, has a "patented family of switched reluctance machines (which) is designed to be the ideal permanent-magnet-less machines" (HEVT, 2010). By applying the technology, it is possible to generate a rare-earth-free generation of electric motors. Similarly, another California startup Nova Torque has found low-cost ferrite magnets to contain in electric motors which results in better performing (Forbes, 2012). Companies like Automotive Suppliers have set up magnet selecting and purchasing team in China.

All these strategies are actively conducted by US companies in response to China's current export quota system. Although some economists are positive about the present situation that US demonstrates a potential to be gradually independent on rare earth imports from China, diminishing sources, unstable market and volatile prices are still likely to remain in the near future.

\section{SUGGESTIONS}

In view of the reactions, GE is seen to have been trying its best to be less affected by China's export policies. Nevertheless, the following additional measures could also be taken into consideration to better achieve its goal.

Firstly, as other non-China suppliers barely produce heavy rare earth metals which are especially needed for GE's lighting industry, import from Greenland seems to be a better option. In recent years, Greenland is discovered with rich rare earth resources lying beneath its vast ice cap which is estimated to occupy at least $25 \%$ of the global demand in the future (Harvey, 2012). More importantly, there is a high concentration of heavy rare earths which is a chance for GE to has an early approach to and negotiate with mining companies in Greenland although it may take time to eventually get access to the materials. In addition, by awareness of the inadequate supply of rare earth market, GE 
should develop deeper links and strike longer deals with supply countries such as Australia, Canada and India to ensure long-term availability.

Secondly, besides every effort to control the prices of its products, GE can learn from a company called Automotive Suppliers to sign "pain-sharing" agreements with OEMs to pass extra cost created by rising rare earth prices to customers (Stuttgart, 2012). Thirdly, it is also important to keep in touch and work closely with other companies, distributors and suppliers so that they can share information to ensure timely updates of rare earth issues and further improve the supply chain visibility. Faced with such a risk, one thing for GE to remember is to build a global connect to win this battle rather than regarding its counterparts as competitors and work alone. Finally, stockpiling might be a choice as some companies have started it to stable the market price.

\section{CONCLUSION}

From this trade dispute, we see how US companies are trying to survive and going through this supply chain crisis caused by Chinese restrictions on rare earth exports. During this process, GE Company has set a good example within the industry and there is a lesson for all business to learn that regarding sustainable development, it is risky for a company or industry to highly rely on a single supply source.

However, problems still remain especially for medium and small enterprises (SMEs) which are unable to react quickly when things like this happen because of the lack of information, R\&D achievements and human resources. It is then left for them and us to think how SMEs can better deal with such problems and finally share a slice of cake in the huge market.

\section{REFERENCES}

[1] Advanced Research Projects Agency-Energy (ARPA-E) (2009), Nanocomposite Magnets \& General Electric Global Research, available at http://arpa-e.energy.gov/?q=arpa-eprojects/nanocomposite-magnets.

[2] Berry, Renee and Torsekar Mihir (2011), Supplies of Critical Rare Earths To U.S. Industries Are Constrained by China's Policies, available

http://www.usitc.gov/publications/332/executive_briefings/Rare_Eart h_EBOT.pdf [March 2011].

[3] Bloomberg (2010), China Cuts Rare Earth Export Quota 72\%, May Spark Trade Dispute with U.S., available at http://www.bloomberg.com/news/2010-07-09/china-reduces-rareearth-export-quota-by-72-in-second-half-lynas-says.html $\left[\begin{array}{ll}9 & \text { July }\end{array}\right.$ 2010].

[4] Brosnan, Kristen (2010), Celebrating Earth Day with Rare Earths: Focus on Material Sustainability at GE, available at http://ge.geglobalresearch.com/blog/celebrating-earth-day-with-rareearths-focus-on-materials-sustainability-at-ge/ [22 April 2010].

[5] Electric Contractor (2011), Tricky Business: Rare-Earth Material Shortage, available http://www.ecmag.com/index.cfm?articleID $=13316 \&$ fa $=$ article [December 2011].

[6] Forbes (2012), China's Rare Earth Metals Monopoly Needn't Put an Electronic Stranglehold on America, available at http://www.forbes.com/sites/larrybel1/2012/04/15/chinas-rare-earth- metals-monopoly-neednt-put-an-electronics-stranglehold-onamerica/2/ [15 April 2012].

[7] GE Citizenship, Rhenium Reduction Program: Using Less of a Rare Mineral, available $\mathrm{http} / / / \mathrm{www}$. gecitizenship.com/blog/features/rhenium-reductionprogram-using-less-of-a-rare-mineral/.

[8] Harvey, Fiona (2012), "The Rare Earth Riches Buried beneath Greenland's Vast Ice Sheet", The Guardian, available at http://www.guardian.co.uk/environment/2012/jul/31/rare-earthgreenland [31 July 2012].

[9] Hybrid Electric Vehicle Technologies (HEVT) (2010), HEVT Focus, available at http://hevt.com/our_focus.html.

[10] Industry News (2012), Rare-Earth Alternative to the Development of the Most Important of the Chinese Air Conditioning Industry, available at http://www.careful.cn/blog/post/121.html [28 September 2012].

[11] Kaye, Leon (2011), With Tight Rare Earth Supplies in Mind, GE Developing New Magnet Technology, available at http://www.triplepundit.com/2011/01/rare-earth-supplies-gedeveloping-new-magnet-technology/ [24 January 2011].

[12] Morrison, Wayne M. and Tang, Rachel (2012), China's Rare Earth Industry and Export Regime: Economic and Trade Implications for the United States, Congressional Research Service, available at http://www.fas.org/sgp/crs/row/R42510.pdf [30 April 2012].

[13] Risk, Materials (2012), Are Rare Earth Metal Prices about to Rise?, available at http://oilprice.com/Metals/Commodities/Are-Rare-EarthMetal-Prices-About-To-Rise.html [24 October 2012].

[14] Shumsky, Tatyana (2011), "Testing Their Metals", The Wall Street Journal, available at http://online.wsj.com/article/SB100014240531119036394045765160 12428805034.html [11 September 2011].

[15] Xinhua (2012), China to Continue Rare Earths Protection, available at http://www.china.org.cn/business/2012-07/25/content_26009043.htm [25 July 2012].

[16] Stuttgart (2012), The Rare Earth Challenge: How Companies React and What They Expected for the Future, available at $\mathrm{http} / / /$ www.rolandberger.us/media/pdf/Roland_Berger_RareEarthCha 1lenge 20120724.pdf [July 2012] 